\title{
PEMANFAATAN LAHAN GAMBUT MENJADI LAHAN POTENSIAL UNTUK MENJAGA KETAHANAN PANGAN DI KALIMANTAN BARAT
}

\author{
Budiman Tampubolon, Diah Trismi Harjanti, Nur Meily Adlika*, Ludovicus Manditya Hari Christanto \\ Program Studi Pendidikan Geografi, Fakultas Keguruan dan Ilmu Pendidikan, Universitas Tanjungpura, Pontianak, Indonesia \\ *nurmeilyadlika@fkip.untan.ac.id:
}

\begin{abstract}
Abstrak Peran sektor pertanian sebagai penyedia sumber pangan dan non pangan berkaitan langsung dengan target SDGs tahun 2030 yakni memberantas kemiskinan dan kelaparan. Di Kabupaten Kubu Raya salah satu wilayah yang berkembang pada sektor pertanian adalah Kecamatan Rasau Jaya dengan hasil bumi utamanya adalah tanaman pangan dan sayuran untuk ketahanan pangan. Lahan pertanian di Kecamatan Rasau Jaya didominasi oleh lahan gambut dengan luas 14.371,392 Ha. Penelitian ini bertujuan untuk mengetahui bentuk pemanfaatan lahan gambut menjadi lahan potensial, peran pertanian sebagai penyedia sumber pangan dan non pangan, serta bentuk pemanfaatannya. Metode yang digunakan adalah metode penginderaan jauh dan metode survei. Hasil penelitian menunjukkan bahwa penggunaan lahan di Kecamatan Rasau Jaya meliputi sawah, kebun, ladang, tegalan, pekarangan, permukiman, hutan, semak belukar, tubuh air, dan lahan kosong. Hasil pertanian tanaman pangan digunakan untuk memenuhi kebutuhan pangan serta kebutuhan non pangan seperti pendidikan dan kesehatan. Sebagian besar masyarakat memanfaatkan hasil panen untuk konsumsi pribadi dan dijual. Masyarakat Kecamatan Rasau Jaya masih belum banyak yang mengolah hasil pertanian menjadi sebuah produk. Petani menjual hasil panen dengan cara antara lain: langsung dijual kepada konsumen, dijual langsung ke pasar dengan membuka kios sendiri, disetorkan kepada tengkulak dan agen, serta diambil oleh pemodal yang menanamkan modalnya kepada petani.
\end{abstract}

Kata kunci: lahan gambut, ketahanan pangan, tanaman pangan

\begin{abstract}
The role of the agricultural sector as a provider of food and non-food sources is directly related to the 2030 SDGs target of eradicating poverty and bunger. In Kubu Raya, one of the developing areas in the agricultural sector is Rasau Jaya District, with main crops being food crops and vegetables for food security. Agricultural land in Rasau Jaya District is dominated by peatlands with 14,371,392 hectares area. This study aims to determine the form of peatland use into potential land, the role of agriculture as a provider of food and non-food sources, and the form of its use. The method used is remote sensing method and survey method. The results showed that land use in the Rasau Jaya District included rice fields, gardens, fields, moor, yards, settlements, forests, shrubs, water bodies, and vacant land. Food crop agricultural products are used to meet food needs as well as non-food needs such as education and health. Most people use the harvest for personal consumption and for sale. There are still not many people in Rasau Jaya District who process agricultural products into a product. Farmers sell their crops in several ways, among others: directly sold to consumers, sold directly to the market by opening their own kiosks, deposited with middlemen and agents, and taken by investors who invest in farmers.
\end{abstract}

Keywords: peatlands, food security, food crops

\section{PENDAHULUAN}

Setiap manusia yang hidup selain memerlukan air dan udara juga memerlukan makan dalam upaya mempertahankan hidupnya. Makanan sangat penting keberadaannya bagi kehidupan manusia, sebab memiliki nutrisi penting yang akan diserap oleh tubuh. Respon tubuh ketika membutuhkan makanan adalah rasa lapar. Eksistensi kegiatan pertanian sangat penting bagi keberlangsungan kehidupan manusia. Selain menyediakan bahan makanan, nutrisi, bahan non pangan, terdapat fungsi lain dari 
eksistensi kegiatan pertanian. Diao et al., (2007) menyebutkan bahwa pertanian merupakan bagian besar dari output nasional sebuah negara yang banyak menyerap tenaga kerja.

Dibalik pentingnya peran pertanian, seringkali terjadi permasalahan. Kompleksitas pertanian terjadi dari tingkat hulu ke hilir. Permasalahan tersebut dikemukakan oleh Bantacut (2014) antara lain: 1) ketersediaan lahan yang semakin sempit; 2) alih fungsi lahan; 3) pemasaran produk pertanian; 4) keragaman produk pertanian; 5) fluktuasi harga; 6) keterbatasan infrastruktur; 7) pembiayaan pertanian terbatas; 8) arah dan kebijakan pembangunan; 9) Sumberdaya manusia; dan 10) Perubahan iklim. Permasalahan tersebut berujung pada ketahanan pangan. Seperti telah diketahui, pangan merupakan kebutuhan dasar utama manusia yang urgensinya tinggi dalam hal ini artinya kebutuhan pangan harus dapat dipenuhi setiap waktu.

Adapun untuk dapat mengukur indeks ketahanan pangan, The Economist Intelligence Unit (EIU) mengembangkan Global Food Security Index (GFSI) yang diperlukan untuk membandingkan situasi ketahanan pangan antar negara berdasarkan aspek ketersediaan, keterjangkauan, serta kualitas dan keamanan pangan. GFSI diadopsi di Indonesia menjadi Indeks Ketahanan Pangan (IKP) (Nurhemi et al., 2014). Adapun data IKP Indonesia dapat dilihat pada gambar 1.

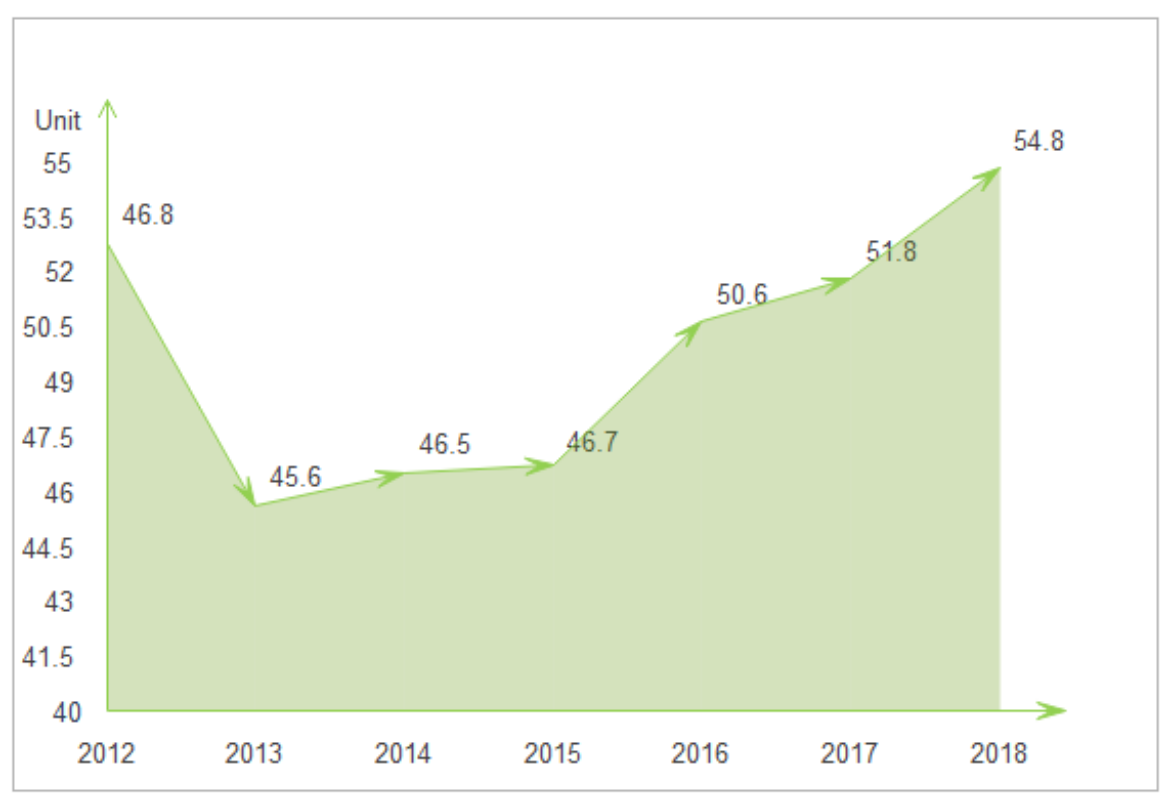

Gambar 1. Indeks Ketahanan Pangan Indonesia 2012-2018 (Sumber: Badan Ketahanan Pangan RI, 2019. Dimodifikasi)

Berdasarkan data yang diterbitkan oleh Badan Ketahanan Pangan, di Indonesia terjadi peningkatan Indeks Ketahanan Pangan selama kurun waktu 2012-2018. Namun demikian, posisi IKP Indonesia tahun 2018 secara global, masih tergolong tertinggal yaitu menempati rangking 65 dari 113 negara. Bahkan di regional ASEAN, Indonesia hanya mampu menduduki peringkat 5. Untuk dapat meningkatkan ketahanan pangan, Indonesia perlu produksi pangan berkuantitas besar dan berkualitas tinggi. Hal ini dapat dilakukan dengan upaya pengoptimalan potensi sumberdaya lahan pertanian, perkebunan, peternakan, perikanan darat, perikanan tangkap. Salah satu wilayah yang berkembang pesat di sektor pertanian di Kabupaten Kubu Raya Kalimantan Barat adalah Kecamatan Rasau Jaya. Wilayah yang terkenal sebagai Kota Terpadu Mandiri dengan hasil bumi utamanya adalah jagung manis dan sayur-sayuran segar yang memasok hampir ke seluruh wilayah Kota Pontianak dan sekitarnya. Wilayah Rasau Jaya merupakan wilayah yang berkembang dan dibangun di atas lahan gambut. Namun, pada dasarnya praktik pengolahan lahan gambut menjadi wilayah pertanian merupakan tantangan bagi wilayah Rasau Jaya. Gambut dengan ketebalan yang berbeda membuat tidak semua jenis tanaman bisa tumbuh dengan baik dan dapat berdapatasi dengan lingkungan Rasau Jaya. Hal ini yang membuat para penduduk Kecamatan Rasau Jaya, baik itu petani maupun non petani (rumah tangga biasa) harus bisa mengolah lahan gambut menjadi lahan yang potensial dan dapat memiliki nilai ekonomis. 
Gambut sendiri adalah material atau bahan organik yang tertimbun secara alami dalam keadaan basah berlebihan atau jenuh air, bersifat tidak mampat dan tidak atau hanya sebagian yang mengalami perombakan (Noor, 2016). Purbo-Hadiwidjoyo dalam Noor (2019) mengatakan bahwa gambut adalah sisa tumbuhan di lingkungan berair yang mulai mengarang, tetapi memiliki kadar lengas yang tinggi sekitar 70\%. Subagyo et al., dalam Noor (2019) juga berpendapat bahwa tanah gambut adalah tanah yang sebagian besar tersusun dari bahan organik dengan kadar C-organik lebih dari $12 \%$ jika tidak mengandung clay atau lempung atau memiliki kadar C-organik lebih dari 18\% jika mengandung clay atau lempung 60\% atau lebih. Widjaya Adhi dalam Barchia (2006) menyebutkan bahwa gambut memiliki kandungan bahan organik lebih dari 85\% dan C organik sebesar 12-18\%, jika BD-nya $>0,1 \mathrm{~g}$ $\mathrm{cm}^{3}$ maka ketebalannya lebih dari $40 \mathrm{~cm}$, akan tetapi jika BD-nya $<0,1 \mathrm{~g} \mathrm{~cm}^{3}$ maka ketebalannya $>60$ $\mathrm{cm}$. lebih lanjut Barchia juga mengkalsifikasikan gambut berdasarkan dua hal yaitu dari ketebalannya dan dari kandungan serat. Berdasarkan ketebalan gambut dibagi menjadi: 1) Gambut dangkal (dengan ketebalan 50-100 cm); 2) Gambut sedang (dengan ketebalan 100-200); 3) Gambut dalam (dengan ketebalan 200-300); 4) Gambut sangat dalam (dengan ketebalan $>300 \mathrm{~cm}$ ). Sedangakan berdasarkan kandungan sertanya, gambut terbagi menjadi: 1) Fibrik, tipe gambut ini memiliki serat yang tinggi yakni lebih dari 66\%, termasuk gambut mentah dengan kematangan gambut kasar; 2) Saprik, mengandung serta kurang dari 1/3 volume dengan kematangan gambut yang sempurna; dan 3) Hemik, gambut tipe ini proses dekomposisinya antara gambut tipe fibrik dan gambut tipe saprik.

Supriatna (2012) mengatakan bahwa lahan gambut dapat dimanfaatkan oleh manusia dalam berbagai hal meliputi hutan, semak belukar, tanaman sawit dan tanaman pangan dan sayuran. Lahan gambut juga dapat berperan sebagai penyedia lapangan pekerjaan, sumber mata pencaharian dan menopang ketahanan pangan bagi masyarakat yang tinggal di atas lahan gambut (Agus et al., 2014). Secara spesifik, lahan gambut dangkal bisa dimanfaatkan sebagai lahan pertanian tanaman pangan dan tanaman hortikultura (Masganti et al., 2017). Tanaman pangan yang dapat ditanam di lahan dengan jenis tanah gambut dangkal adalah padi, jagung, kedelai, dan ubi kayu. Tanaman holtikultura yang dapat berkembangan di lahan gambut dangkal adalah jenis tanaman buah-buahan seperti nanas, semangka, melon serta jenis sayuran seperti timun, cabai, tomat.

Dalam sepuluh tahun terakhir beberapa penelitian fokus pada pemanfaatan lahan gambut. Di antaranya berkaitan dengan upaya pengelolaan lahan gambut dengan menerapkan teknis dan sentuhan teknologi agar dapat lebih efektif dan produktif (Sabiham et al., 2012; Yuliani \& Selatan, 2014). Ada pula penelitian yang mengkaji tentang upaya rehabilitasi lahan gambut agar dapat dijadikan lahan yang lebih produktif. Misalnya mengidentifikasi peran dan dukungan parapihak dalam upaya rehabilitasi lahan gambut (Martin \& Winarno, 2010); dampak lingkungan dari alih fungsi lahan gambut (Widyati, 2011); menganalisis kondisi lingkungan biofisik lahan gambut (Sabiham \& Pramudya, 2010); serta mengidentifikasi peran kearifan local yang dapat mengurangi degradasi lahan gambut (Firmansyah \& Mokhtar, 2011). Selain itu terdapat pula penelitian terkait usahatani di lahan gambut (Nazeb et al., 2019; Noor et al., 2014; Susanti et al., 2015; Sasli \& Ruliansyah, 2012). Salah satu penelitian yang cukup penting juga yaitu terkait pemetaan lahan gambut, khususnya lahan untuk pertanian kelapa sawit (Krisnohadi, 2011). Namun penelitian tersebut hanya fokus pada satu jenis lahan saja, yaitu lahan kelapa sawit tanpa memetakan lahan gambut untuk peruntukan (landuse) lainnya. Kondisi ini tentunya menjadi celah kosong yang harus diisi. Oleh sebab itu penelitian ini akan difokuskan pada upaya pemanfaatan lahan gambut untuk lahan potensial di Kalimantan Barat, khususnya di Kecamatan Rasau Jaya Kabupaten Kubu Raya.

Selain alasan pengembangan ilmu pengetahuan, penelitian ini juga didasari oleh adanya permasalahan. Mulyani et al., (2011) dalam penelitiannya menyatakan bahwa dalam kurun waktu 40 tahun yaitu dari tahun 2010-2050 terjadi kenaikan permintaan bahan pangan yaitu beras sebesar 15,12 juta ton. Hal ini menjadi permasalahan jika dalam pemenuhannya hanya berpatokan pada lahan sawah. Memanfaatkan lahan gambut sebagai lahan potensial untuk memenuhi kebutuhan pangan dapat menjadi alternatif solusi. Rasau Jaya sebagai wilayah dengan jenis tanah gambut dimanfaatkan sebagian masyarakat sebagai sumber matapencaharian seperti bertani dan berkebun. Dari hal ini tentunya perlu diketahui bagaimana masyarakat Kecamatan Rasau Jaya memanfaatkan lahan gambut menjadi lahan 
potensial, peran sektor pertanian sebagai penyedia sumber pangan dan non pangan dan bentuk pemanfaatan pangan oleh masyarakat di Kecamatan Rasau Jaya.

\section{METODE PENELITIAN}

Penelitian ini dilakukan di Kecamatan Rasau Jaya Kabupaten Kubu Raya. Secara astronomis

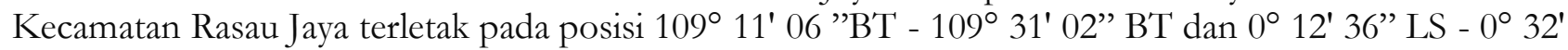
07 “ LS. Kecamatan Rasau Jaya terdiri dari 6 desa yaitu desa Rasau Jaya Umum, desa Rasau Jaya Satu, desa Rasau Jaya Dua, desa Rasau Jaya Tiga, desa Bintang Mas, dan desa Pematang Tujuh. Untuk lebih jelasnya dapat dilihat pada gambar 1 .

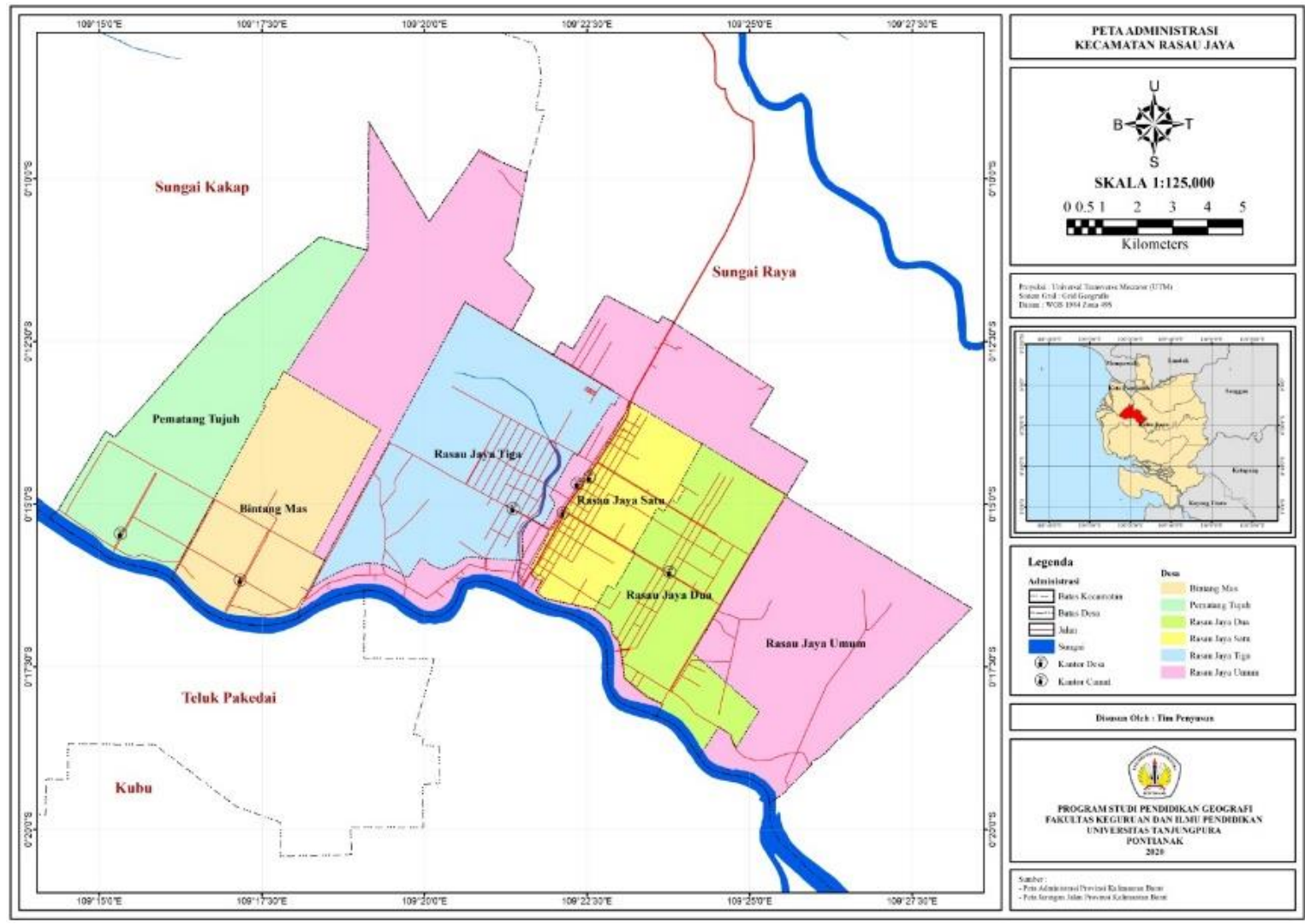

Gambar 1. Peta Administratif Kecamatan Rasau Jaya

(Sumber : Peneliti, 2020)

Penelitian ini merupakan penelitian deskriptif dengan pendekatan kuantitatif. Secara spesifik menggunakan metode penginderaan jauh dan metode survei (Bungin, 2005). Metode penginderaan jauh adalah metode yang digunakan untuk membangun data spasial dengan menggunakan teknik interpretasi Citra Penginderaan Jauh, Sedangkan metode survey adalah penelitian yang mengambil sampel dari satu populasi dan menggunakan kuisioner sebagai alat pengumpulann data yang pokok. Pada metode penginderaan jauh peneliti menggunakan teknik interpretasi citra. Dalam teknik interpretasi citra terdapat cara-cara yang menguntungkan yang dapat diartikan dalam segi kemudahan pelaksanaan interpretasi, lebih akurat hasil interpretasinya atau lebih banyak informasi yang dapat diperoleh (Sutanto, 2013). Untuk metode penginderan jauh tahapan yang dilakukan dalam penelitian ini yaitu 1) menetapkan data acuan; 2) menyiapkan data penginderaan jauh; 3) membangun klasifikasi penggunaan lahan; 4) membangun kunci interpretasi; dan 5) interpretasi citra dan uji akurasi.

\section{Menetapkan Data Acuan}

Data acuan merupakan data yang diperlukan untuk mendukung proses interpretasi citra tetapi data tersebut tidak diperoleh dari citra penginderaan jauh. Penggunaan data acuan yang ada akan meningkatkan ketelitian hasil interpretasi citra. Data acuan yang digunakan dalam hal ini adalah peta kecamatan Rasau Jaya yang dapat dijadikan sebagai acuan dalam interpretasi citra. 


\section{Menyiapakan Data Penginderaan Jauh}

Data penginderaan jauh ialah data hasil perekaman obyek dengan menggunakan sensor buatan. Ia dapat berupa citra foto, citra non foto atau data numeric. Bila dipilih data berupa citra, maka metode analisisnya adalah analisis visual atau analisis manual. Bila data numerik, maka dilakukan analisis digital dengan menggunakan komputer. Bila dipilih data citra, jenis dan skalanya disesuaikan dengan tujuan penelitian. Dalam penelitian ini data yang digunakan adalah data citra penginderaan jauh wilayah kecamatan Rasau Jaya.

\section{Membangun Klasifikasi Penggunaan Lahan}

Klasifikasi penggunaan lahan yang digunakan dalam penelitian ini adalah klasifikasi penggunaan lahan yang digunakan oleh Sutanto (2013) dengan modifikasi yang selanjutnya dapat dilihat pada tabel 1.

Tabel 1. Klasifikasi Penggunaan Lahan Menurut Sutanto Dengan Modifikasi

\begin{tabular}{ccc}
\hline No & Kelas Penggunaan Lahan & Kelas Penggunaan Lahan Potensial \\
\hline 1 & Sawah & Lahan Potensial Untuk Pertanian \\
2 & Ladang & Lahan Potensial Untuk Pertanian \\
3 & Tegalan & Lahan Potensial Untuk Pertanian \\
4 & Kebun & Lahan Potensial Untuk Pertanian \\
5 & Pekarangan & Lahan Potensial Untuk Pertanian \\
6 & Hutan & Lahan Potensial Bukan Untuk Pertanian \\
7 & Semak Belukar & Lahan Potensial Bukan Untuk Pertanian \\
8 & Permukiman & Lahan Potensial Bukan Untuk Pertanian \\
\hline
\end{tabular}

Sumber : Sutnto, 2013.

\section{Membangun Kunci Interpretasi}

Membangun kunci interpretasi citra dimaksudkan sebagai pedoman dalam melaksanakan intepretasi citra. Kunci interpetasi untuk obyek sawah dalam penelitian ini dibangun dari warna pada citra penginderaan jauh yaitu hijau, bentuk persegi, tekstur halus, pola luas berpetak-petak teratur, situs ada saluran irigasi dan asosiasi berdekatan dengan petak lahan teratur yang lain dan permukiman.

\section{Interpretasi Citra dan Uji Akurasi}

Teknik interpretasi citra yang digunakan dalam penelitian ini mengacu pada 2 kegiatan utama yaitu 1) penyadapan data dari citra dan 2) penggunaan data tersebut untuk tujuan tertentu. Penyadapan data dari citra berupa pengenalan obyek dan elemen yang tergambar pada citra serta penyajiannya ke peta tematik yang dalam hal ini adalah peta pengunaan lahan. Dalam penelitian ini pekerjaan medan dilakukan dengan mengecek obyek hasil interpretasi citra yang kebenarannya masih diragukan. Selanjutnya data yang disadap dari citra dan telah diuji akurasi, harus dimanfaatkan sesuai dengan tujuan tertentu. Dalam penelitian ini data yang disadap dari citra yang berwujud data penggunaan lahan yang selanjutnya dimanfaatkan untuk analisis dalam melihat sebaran pemanfaatan lahan potensial pada lahan gambut di kecamatan Rasau Jaya. Dalam metode survei ini informasi dikumpulkan dari responden dengan menggunakan kuesioner. Pengertian survei ini dibatasi pada pengertian survei sampel dimana informasi dikumpulkan dari sebagian populasi untuk mewakili seluruh populasi. Penelitian ini terbatas pada usaha mengungkapkan suatu masalah atau keadaan sebagaimana adanya sehingga bersifat sekedar untuk mengungkapkan fakta (Effendi et al., 2012).

Populasi dalam penelitian ini adalah seluruh desa yang ada di kecamatan Rasau Jaya, sedangkan sampel dalam penelitian ini adalah beberapa desa yang dipilih sebagai tempat kegiatan survey untuk penggalian data primer guna menjawab tujuan penelitian. Teknik pengambilan sampel dilakukan secara purposive dengan mempertimbangkan analisis kesesuaian lahan yang telah disusun berdasarkan tujuan penelitian. Pengambilan jumlah sampel menggunakan rumus slovin, yang merupakan untuk menghitung banyaknya sampel minimum suatu survei populasi terbatas dengan tujuan untuk mengestimasi proporsi populasi. 
Adapun rumus slovin yang digunakan adalah:

$$
\mathrm{n}=\mathrm{N} /\left(1+\mathrm{Ne}^{2}\right)
$$

Sumber: Setiawan (2007)

Keterangan :

$\mathrm{n}=$ Jumlah Sampel

$\mathrm{N}=$ Besar Populasi/Jumlah Populasi

$\mathrm{e}=$ Batas Toleransi Kesalahan (error tolerance)

Berdasarkan rumus diatas maka diperoleh perhitungan jumlah sampel pada penelitian ini adalah sebagai berikut :

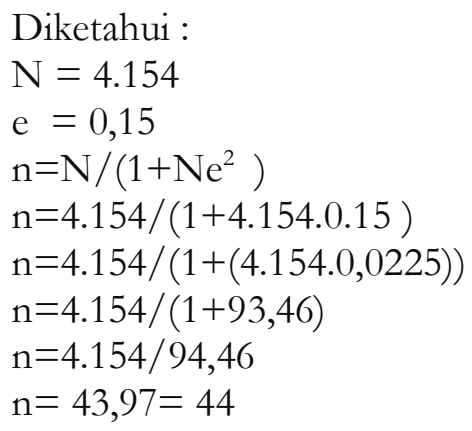

Dari perhitungan diatas didapatkan jumlah responden ialah sebanyak 44 orang.

Langkah langkah dalam penelitian ini meliputi: 1) tahap persiapan (studi pustaka dan literature mengenai tema penelitian; mempersiapkan data citra penginderaan jauh, peta RBI, peta sebaran lahan gambut, dan peta peta tematik yang relevan); 2) tahap pelaksanaan (inventaris data sekunder dan data data spasial yang ada untuk dilakukan pengolahan serta analisis data spasial untuk pemodelan kesesuaian lahan; penentuan titik sampel di lapangan untuk penggalian data primer; kerja lapangan dan wawancara dengan responden; pengolahan dan analisis data lapangan); dan 3) tahap akhir berupa penyusunan laporan hasil penelitian. Adapun alat pengumpulan data yang utama digunakan dalam penelitian ini adalah: 1) Peta RBI wilayah Rasau Jaya dan sekitarnya; 2) Citra penginderaan jauh Kecamatan Rasau Jaya, untuk menyadap informasi penggunaan lahan; 3) Peta distribusi lahan gambut di Kecamatan Rasau Jaya; 4) Peta tematik yang relevan untuk pemodelan spasial kesesuaian lahan pertanian; 5) Kuesioner. Setelah itu data yang telah terkumpul melalui alat pengumpulan data akan diolah dan disajikan dalam bentuk peta, grafik dan tabel. Selanjutnya data yang disajikan akan dianalisis untuk memecahkan permasalahan penelitian yang diajukan.

\section{TEMUAN DAN PEMBAHASAN}

\section{Pemanfaatan Lahan Gambut Menjadi Lahan Potensial}

Sektor pertanian memiliki banyak peranan penting dalam berbagai aspek, diantaranya ialah penyedia sumber pangan dan non pangan. Peran sebagai penyedia sumber pangan dan non pangan menyebabkan peningkatan produksi komoditas pertanian menjadi target penting seiring dengan semakin meningkatnya kebutuhkan akan sumber pangan maupun non pangan. Diharapkan, dengan terpenuhinya penyediaan sumber pangan dan non pangan dari sektor pertanian lokal maka akan mengurangi angka impor sumber pangan dan non pangan. Pemanfaatan lahan potensial untuk sawah di Kecamatan Rasau Jaya adalah seluas 2.026 Ha. Lahan sawah banyak tersebar pada wilayah sepanjang sungai karena karakteristik sawah yang basah memanfaatkan sungai untuk saluran irigasi. Sungai yang melintas pada wilayah selatan Kecamatan Rasau Jaya membuat sawah memiliki pola memanjang dan juga pada wilayah tengah. Pola persebaran sawah tidak jauh berbeda dengan pola persebaran permukiman. Pola permukiman pada Kecamatan Rasau Jaya juga didominasi mengikuti aliran sungai baik sungai besar maupun sungai kecil (parit). Total luas lahan potensial seluruhnya adalah $10.798 \mathrm{Ha}$ 
dari total luas Kecamatan Rasau Jaya yaitu 21.415 Ha. Luas penggunaan lahan untuk lebih detailnya dapat dilihat pada tabel 2 .

Tabel 2. Luas Penggunaan Lahan Kecamatan Rasau Jaya

\begin{tabular}{ccc}
\hline No & Objek & Luas (Ha) \\
\hline 1 & Sawah & 2.026 \\
2 & Kebun & 7.341 \\
3 & Ladang & 752 \\
4 & Tegalan & 555 \\
5 & Pekarangan & 124 \\
6 & Permukiman & 263 \\
7 & Hutan & 1.274 \\
8 & Semak Belukar & 6.384 \\
9 & Tubuh Air & 480 \\
10 & Lahan Kosong & 2.216 \\
& Total & $\mathbf{2 1 . 4 1 5}$ \\
\hline
\end{tabular}

Sumber: Hasil analisis, 2020.

Pemanfaatan lahan potensial di Kecamatan Rasau Jaya meliputi lahan sawah, kebun, ladang, tegalan, dan pekarangan. Kecamatan Rasau Jaya memiliki lahan sawah dengan luas $2.026 \mathrm{Ha}$. Pemanfaatan lahan untuk sawah terbagi atas desa-desa yang terdiri dari 6 desa yaitu meliputi Desa Rasau Jaya Umum seluas 615 Ha, Desa Rasau Jaya Satu seluas 548 Ha, Desa rasau Jaya Dua seluas 353 Ha, Desa Rasau Jaya Tiga seluas $340 \mathrm{Ha}$, Desa Pematang Tujuh seluas $23 \mathrm{Ha}$, dan Desa Bintang Mas seluas 147 Ha. Sebaran penggunaan lahan di Kecamatan Rasau Jaya dapat dilihat gambar 2.

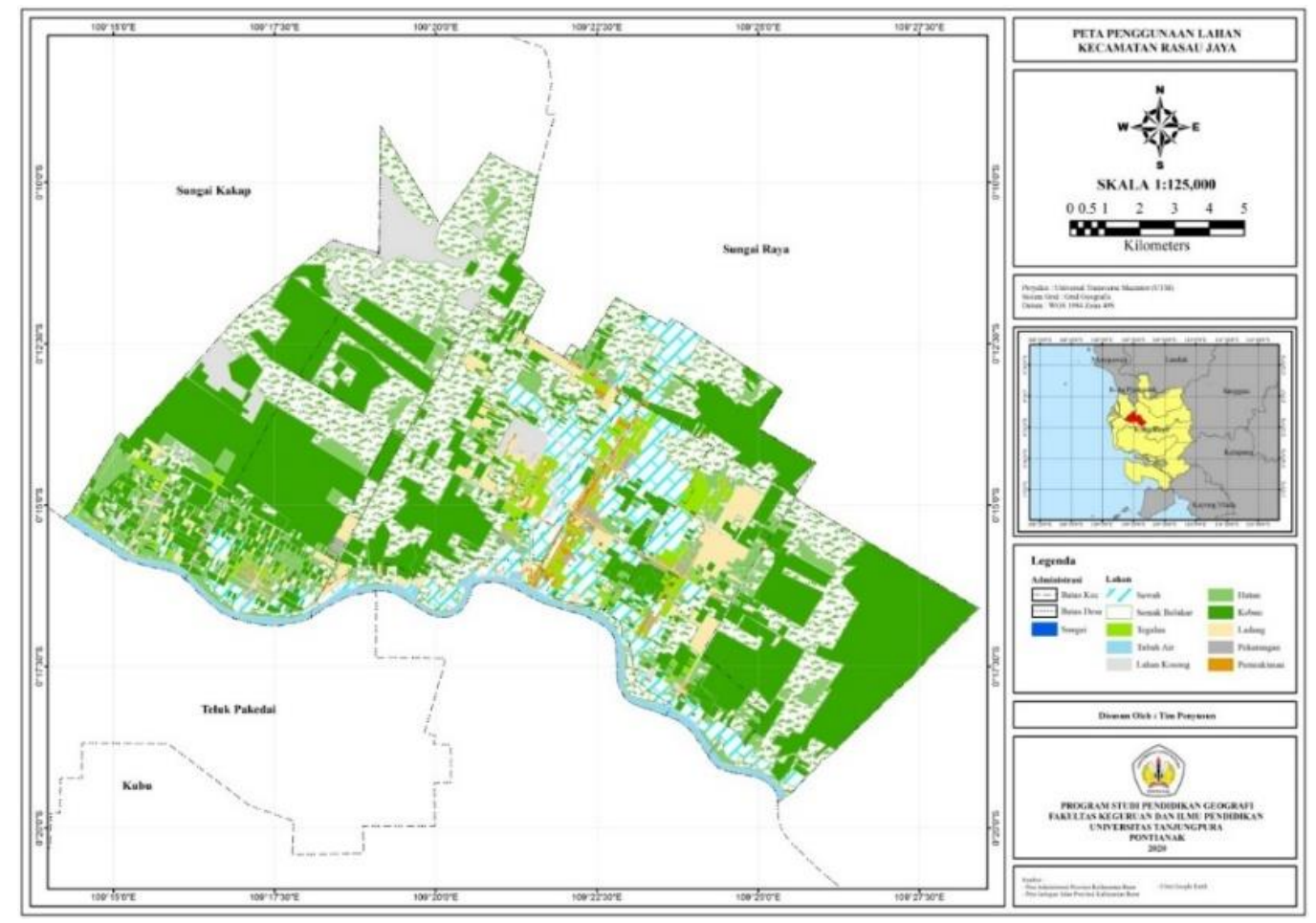

Gambar 2. Peta Penggunaan Lahan Kecamatan Rasau Jaya (Sumber: Hasil Digitasi, 2020)

Pemanfaatan lahan potensial untuk lahan kebun di Kecamatan Rasau Jaya dengan total luasan yaitu $7.342 \mathrm{Ha}$. Sedangkan pemanfaatan lahan kebun per desa yang terluas adalah berada di Desa Rasau Jaya Umum yaitu 3.390 Ha. Kemudian Desa Pematang Tujuh yaitu seluas 1.450 Ha, Desa Bintang Mas seluas 1.070 Ha, Desa Rasau Jaya Tiga seluas 772 Ha, Desa Rasau Jaya Dua seluas 505 Ha, dan Desa 
Rasau Jaya Satu seluas $155 \mathrm{Ha}$. Jika diukur dengan perbandingan luas wilayah masing-masing desa, maka desa yang wilayahnya didominasi oleh lahan perkebunan adalah Desa Bintang Mas. Lahan yang dimanfaatkan untuk ladang adalah seluas $752 \mathrm{Ha}$ di Kecamatan Rasau Jaya. Penggunaan lahan per desa di Kecamatan Rasau Jaya adalah meliputi Desa Rasau Jaya Tiga seluas $225 \mathrm{Ha}$, Desa Pematang Tujuh seluas $75 \mathrm{Ha}$, Desa Rasau Jaya Umum seluas $75 \mathrm{Ha}$, Desa Bintang Mas seluas $48 \mathrm{Ha}$, Desa Rasau Jya Satu seluas $45 \mathrm{Ha}$, dan Desa Rasau Jaya Dua seluas $20 \mathrm{Ha}$. Pemanfaatan lahan untuk tegalan di Kecamatan Rasau Jaya didapatkan dengan total luas lahan yaitu 555 Ha. Luas pemanfaatan lahan potensial untuk tegalan per desa yaitu meliputi Desa Rasau Jaya Dua seluas 164 Ha, Desa Rasau Jaya Satu seluas 143 Ha, Desa Rasau Jaya Tiga seluas 131, Desa Pematang Tujuh seluas 54 Ha, Desa Rasau Jaya Umum seluas $38 \mathrm{Ha}$, dan Desa Bintang Mas seluas $25 \mathrm{Ha}$. Lahan yang dimanfaatkan sebagai lahan pekarangan di Kecamatan Rasau Jaya adalah $124 \mathrm{Ha}$. Pemanfaatan lahan per desa yaitu meliputi Desa Rasau Jaya Satu seluas $45 \mathrm{Ha}$, Desa Rasau Jaya seluas $20 \mathrm{Ha}$, Desa Bintang Mas seluas $20 \mathrm{Ha}$, Desa Rasau Jaya Umum seluas 19 Ha, Desa Pematang Tujuh seluas 11 Ha, dan Desa Rasau Jaya Tiga seluas 9 Ha.

\section{Bentuk Pemanfaatan Pangan oleh Masyarakat}

Pemanfaatan lahan terutama lahan gambut, oleh masyarakat di wilayah Kecamatan Rasau Jaya dimanfaatkan sebagai lahan pertanian terutama pertanian tanaman pangan. Pada lahan yang ditanami tersebut masyarakat banyak menanan tanaman seperti padi, jagung, ubi dan ketela. Kegiatan pasca panen yang dilakukan petani Kecamatan Rasau Jaya didapatkan jawaban jika hasil panen akan diolah menjadi barang/makanan yang memiliki nilai tambah dari segi ekonomi. Misalnya ubi jalar akan diolah menjadi makanan ketimus/lobi-lobi yang akan dijual ke konsumen dalam kondisi siap santap. Dari sistem penjualan yang dilakukan petani didapatkan data bahwa hasil panen dijual langsung kepada konsumen, dijual kepada tengkulak, dan sisanya menjawab hasil panen di kirim langsung ke pasar, pedagang/warung, serta ada pula yang diambil oleh pemodal yang menyewakan lahannya kepada petani. Untuk para petani yang langsung mengirim ke pasar dan tengkulak/agen sayur biasanya akan mengirim hasil panen ke pasar-pasar sentral yang ada di Kota Pontianak dan sekitarnya seperti Pasar Flamboyan, Pasar Mawar, Pasar Dahlia dan lainnya.

\section{Peran Sektor Pertanian Sebagai Penyedia Sumber Pangan dan Non Pangan}

Penduduk Kecamatan Rasau Jaya sebagian besar merupakan transmigran dengan mayoritas matapencahariannya sebagai petani yang sangat bergantung pada ketersediaan lahan untuk memenuhi kebutuhan. Komoditi yang umumnya dihasilkan di Kecamatan Rasau Jaya adalah padi, jagung, ubi, dan sayur-sayuran. Padi yang diproduksi di Kecamatan Rasau Jaya umumnya digunakan sebagai sumber pangan bagi petani. Sedangkan untuk jagung, ubi dan sayur-sayuran petani menjual kepada pengepul untuk mendapatkan uang. Dari pengepul kemudian hasil produksi tanaman pangan akan disuplay ke daerah-daerah sekitar diantaranya ialah Kota Pontianak. Uang yang diperoleh dari sektor pertanian kemudian dimanfaatkan oleh para petani untuk memenuhi kebutuhan non pangan, seperti kebutuhan pendidikan dan kesehatan.

Diketahui bahwa total luas kebun yang ada di Kecamatan Rasau Jaya adalah $7.342 \mathrm{Ha}$ atau sekitar 66,13 \% dari luas wilayah Kecamatan Rasau Jaya. Dengan demikian dapat dilihat bahwa sektor pertanian dapat memenuhi kebutuhan sumber pangan dan non pangan untuk Kecamatan Rasau Jaya sendiri bahkan sebagian besar hasil pertanian dari Kecamatan Rasau Jaya di distribusikan ke luar Kecamatan Rasau Jaya. Dari hal ini dapat dilihat bahwa sektor pertanian memiliki peran yang sangat penting bagi petani untuk mendapatkan penghasilan guna memenuhi kebutuhannya. Selain itu, masyarakat Kecamatan Rasau Jaya dapat dengan mudah memperoleh kebutuhan pangan tentunya dengan harga yang terjangkau karena dekat dengan sumber produksi pangan. Terdapat pula kesempatan untuk memperoleh pendapatan dari hasil pertanian dengan cara menjadi buruh tani dan sebagai pengepul untuk mendistribusikan hasil pertanian keluar dari Kecamatan Rasau Jaya. Tingkat ketahanan pangan di wilayah Kecamatan Rasau Jaya dapat dikategorikan baik. Hal ini disebabkan karena hasil panen tanaman pangan seperti padi, jagung, ubi dan ketela mampu di jual ke luar wilayah Kecamatan Rasau Jaya dikarenakan di dalam wilayah Rasau Jaya telah mengalami surplus. 


\section{SIMPULAN}

Berdasarkan hasil penelitian dapat disimpulkan bahwa luas total lahan gambut di Kecamatan Rasau Jaya yaitu 14.371,392 Ha yang terdiri dari lahan gambut dengan kedalaman dangkal seluas $6.061,352 \mathrm{Ha}$ dan lahan gambut dengan kedalaman sedang seluas 8.310,041 $\mathrm{Ha}$, serta lahan bukan gambut seluas 7.043,930 Ha. Total luas lahan potensial seluruhnya adalah $10.798 \mathrm{Ha}$ dari total luas Kecamatan Rasau Jaya yaitu 21.415 Ha. Pemanfaatan lahan potensial meliputi lahan sawah, kebun, ladang, tegalan, dan pekarangan. Lahan sawah yang dimanfaatkan di Kecamatan Rasau Jaya adalah dengan total luas 2.026 Ha. Total luas kebun yang ada di Kecamatan Rasau Jaya adalah 7.342 Ha atau sekitar 66,13 \% dari luas wilayah Kecamatan Rasau Jaya. Dengan demikian dapat dilihat bahwa sektor pertanian dapat memenuhi kebutuhan sumber pangan dan non pangan untuk Kecamatan Rasau Jaya sendiri bahkan sebagian besar hasil pertanian dari Kecamatan Rasau Jaya didistribusikan ke luar Kecamatan Rasau Jaya.

\section{DAFTAR PUSTAKA}

Agus, F., Anda, M., \& Jamil, A. (2014). Lahan Gambut Indonesia: Pembentukan, Karakteristik, dan Potensi Mendukung Ketahanan Pangan. Jakarta: Badan Penelitian dan Pengembangan Pertanian.

Badan Ketahanan Pangan Kementrian Pertanian. (2019). Laporan Kinerja Pusat Ketersediaan dan Kerawanan Pangan Tabun 2018. Jakarta: Kementerian Pertanian Republik Indonesia.

Bantacut, T. (2014). Agenda Pembangunan Pertanian dan Ketahanan Pangan 2014-2019 (Agenda of Agricultural Development and Food Security 2014-2019). Jurnal Pangan, 23(3), 278-295.

Barchia, M. F. (2006). Gambut: Agroekosistem dan Transformasi Karbon. Gadjah Mada University Press.

Bungin, B. (2005). Metodelogi Penelitian Kuantitatif. Jakarta: Kencana Premnadamedia Group.

Diao, X., Hazell, P. B., Resnick, D., \& Thurlow, J. (2007). The role of agriculture in development: Implications for Sub-Sabaran Africa (Vol. 153). Intl Food Policy Res Inst.

Effendi, Sofian \& Tukiran. (2012). Metode Penelitian Survei. Jakarta: Penerbit LP3ES

Firmasyah, M. A., \& Mokhtar, M. S. (2011). Kearifan Lokal Pemanfaatan Lahan Gambut untuk Usahatani dalam Mengantisipasi Dampak Perubahan Iklim di Kalimantan Tengah. Workshop Nasional Adaptasi Perubahan Iklim di Sektor Pertanian (Vol. 8).

Krisnohadi, A. (2011). Analisis Pengembangan Lahan Gambut untuk Tanaman Kelapa Sawit Kabupaten Kubu Raya. Jurnal Teknik Perkebunan, 1(1), 1-7.

Martin, E., \& Winarno, B. (2010). Peran Parapihak dalam Pemanfaatan Lahan Gambut; Studi Kasus di Kabupaten Ogan Komering Ilir, Sumatera Selatan. Jumal Analisis Kebijakan Kebutanan, 7(2), 81-95.

Masganti, M., Anwar, K., \& Susanti, M. A. (2017). Potensi dan Pemanfaatan Lahan Gambut Dangkal untuk Pertanian. Jurnal Sumberdaya Lahan, 11(1): 43-52.

Mulyani, A., Ritung, S., \& Las, I. (2011). Potensi dan Ketersediaan Sumberdaya Lahan untuk Mendukung Ketahanan Pangan. Jurnal Penelitian dan Pengembangan Pertanian, 30(2), 73-80.

Nazeb, A., Darwanto, D. H., \& Suryantini, A. (2019). Efisiensi Alokatif Usahatani Padi pada Lahan Gambut di Kecamatan Pelalawan, Kabupaten Pelalawan, Riau. Jurnal Ekonomi Pertanian dan Agribisnis, 3(2), 267-277.

Noor, M. (2016). Lahan Gambut: Pengembangan, Konservasi, dan Perubahan Iklim. Yogyakarta: Gadjah Mada University Press.

Noor, M. (2019). Kebakaran Lahan Gambut: Dari Asap Sampai Kanalisasi. Yogyakarta: Gadjah Mada University Press.

Noor, M., Nursyamsi, D., Alwi, M., \& Fahmi, A. (2014). Prospek Pertanian Berkelanjutan di Lahan Gambut: Dari Petani ke Peneliti dan Peneliti ke Petani. Jurnal Sumberdaya Laban, 8(2), 69-79. 
Nurhemi, S. R., Soekro, G. S. R., \& Suryani, R. (2014). Pemetaan Ketahanan Pangan di Indonesia: Pendekatan TFP dan Indeks Ketahanan Pangan. Jakarta: Bank Indonesia.

Sabiham, S., \& Pramudya, B. (2010). Analisis Lingkungan Biofisik Lahan Gambut pada Perkebunan Kelapa Sawit. Jurnal Hidrolitan, 1(3), 20-28.

Sabiham, S., Lahan, S., \& Sukarman, S. (2012). Pengelolaan Lahan Gambut untuk Pengembangan Kelapa Sawit di Indonesia. Jurnal Sumberdaya Laban, 6(2), 55-66.

Sasli, I., \& Ruliansyah, A. (2012). Pemanfaatan Mikoriza Arbuskula Spesifik Lokasi untuk Efisiensi Pemupukan pada Tanaman Jagung di Lahan Gambut Tropis. Agrovigor: Jurnal Agroekoteknologi, 5(2), 65-74.

Setiawan, N. (2007). Penentuan Ukuran Sampel Memakai Rumus Slovin dan Tabel Krejcie-Morgan: Telaah Konsep dan Aplikasinya. Bandung: Universitas Padjadjaran.

Supriatna, W. (2012). Emission Reduction Options for Peatlands in the Kubu Raya and Pontianak Districts, West Kalimantan, Indonesia. Journal of Oil Palm Research, 24, 1378-1387.

Susanti, P. D., Wahyuningtyas, R. S., \& Ardhana, A. (2015). Pemanfaatan Gulma Lahan Gambut Sebagai Bahan Baku Bio-briket. Jurnal Penelitian Hasil Hutan, 33(1), 35-46.

Sutanto. (2013). Metode Penelitian Penginderaan Jauh. Yogyakarta: Penerbit Ombak.

Widyati, E. (2011). Kajian optimasi pengelolaan lahan gambut dan isu perubahan iklim. Tekno Hutan Tanaman, 4(2), 57-68.

Yuliani, N., \& Selatan, K. (2014). Teknologi Pemanfaatan Lahan Gambut untuk Pertanian. In Prosiding Seminar Nasional InovasiTeknologi Pertanian Spesifik Lokasi, 6(7), 361-373. 